\title{
HUBUNGAN LAMA PENGGUNAAN OBAT ARV TERHADAP KADAR HEMOGLOBIN PADA PENDERITA HIV/AIDS DI POLI VCT RSUD PROF. DR. SOEKANDAR KABUPATEN MOJOKERTO
}

\author{
Indah Lestari*, Emyk Windartik**, Gendewa Goa Wijaya*** \\ STIKes Bina Sehat PPNI Kabupaten Mojokerto
}

\begin{abstract}
Antiretroviral (ARV) therapy was undertaken with HIV/AIDS by took medication for life, to suppress the amount of virus. Most people took antiretroviral (ARV) drugs had some side effects, one of which decreased in hemoglobin $(\mathrm{Hb})$, which was influenced by factors duration of therapy and CD4 levels. As a result of long use of antiretroviral (ARV) drugs by the side effects that cause a decrease in hemoglobin. The research objective was to determine the relationship of long used of ARV (Antiretroviral) on levels of hemoglobin in people with HIV / AIDS. The research design corelation analytical with cross sectional approach. Entired population HIV/AIDS patients undergoing antiretroviral therapy in Polyclinic VCT at Prof. Dr. Soekandar Hospital District Mojokerto regency as many as 65 respondents. Samples of 25 respondents took by purposive sampling. Old data retrieval use of ARV drugs by used observations of medical records and hemoglobin concentration used check tool hemoglobin (Hb Quick Chek) and secondary data. Test data analysis using the Spearman rho shows $\rho(0.002)<\alpha(0.05)$, it means that there is a long standing relationship to the use of ARV drugs hemoglobin levels. Decreases in hemoglobin may occur due to antiretroviral drugs tend to inhibit the enzyme reverse transcriptase and cause damage to the spinal cord so that hemoglobin in the blood is very low which leads to anemia. One way to suppress the occurrence of side effects can be done by taking supplements that can increase the levels of hemoglobin in the blood.
\end{abstract}

\section{Keywords: Antiretoviral (ARV), Hemoglobin Levels, HIV / AIDS}

\begin{abstract}
Pendahuluan
Masalah HIV/AIDS (Human

Immunodeficiency Virus atau Acquired

Immuno Deficiency Sindrom) merupakan

masalah kesehatan yang mengancam Indonesia dan banyak negara di dunia. Saat ini tidak ada negara yang terbebas dari masalah HIV/AIDS (Veronica, 2013). Pengidap HIV memerlukan pengobatan dengan antiretroviral (ARV) untuk menekan jumlah virus dengan menghambat proses replikasi virus HIV dalam sel CD4 sehingga dapat menurunkan jumlah virus HIV di dalam tubuh agar tidak masuk ke dalam stadium AIDS (Green, 2009).

Tahun 2013 ada 35 juta orang hidup dengan HIV yang meliputi 16 juta perempuan dan 3,2 juta anak < 15tahun. Jumlah kematian akibat AIDS mencapai 1,5 juta yang terdiri dari 1,3 juta dewasa dan 190.000 anak usia < 15 tahun(WHO, 2014). Biro pusat statistik melaporkan tambahan kasus HIV/AIDS di Indonesia sampai dengan September 2014 menyebutkan bahwa jumlah HIV/AIDS sebanyak 22.869 orang terinfeksi
\end{abstract}

HIV dan sebanyak 1.876 orang telah masuk dalam fase AIDS (Ditjen PP \& PL Kemenkes RI, 2014). Jawa timur merupakan provinsi penyumbang terbanyak kasus AIDS kedua setelah Papua dan diikuti oleh DKI Jakarta posisi ketiga di Indonesia. Berdasarkan laporan provinsi jumlah kasus kumulatif AIDS mulai dari 1987 sampai september 2014 yaitu 12.347 kasus, sedangkan jumlah total kasus kumulatif HIV sebanyak 19.249 kasus (Kementerian Kesehatan RI, 2015). Jumlah penderita kasus HIV di Kabupaten/Kota Mojokerto pada tahun 2012 yaitu 284 kasus HIV, 137 kasus AIDS sedangkan pada tahun 2013 menjadi 372 kasus HIV dan kasus AIDS menjadi 176 kasus. Terjadi peningkatan kasus pada tahun 2013, hal ini menunjukan bahwa semakin besar kasus HIV/AIDS. (Dinas Kesehatan Kabupaten/Kota Mojokerto, 2014).

Hasil studi pendahuluan yang dilakukan di Poli VCT RSUD Prof. Dr. Soekandar Kabupaten Mojokerto tanggal 21 Desember 2015 dengan cara melakukan wawancara dan observasi didapatkan data penderita 
HIV/AIDS sebanyak 95 orang. Penggunaan obat ARV (antiretroviral) dengan rincian program memenuhi syarat untuk menggunakan obat ARV sebanyak 65 orang, belum memenuhi syarat untuk menggunakan obat ARV sebanyak 30 orang. Berdasarkan data rekam medis pada masa pengobatan terhadap penurunan hemoglobin $(\mathrm{Hb})$ sebanyak 8 penderita, didapatkan data sebagai berikut 4 orang terdapat penurunan $\mathrm{Hb}$ tampak pada bulan ketiga terapi ARV dan 4 orang tampak saat lebih dari satu tahun.

Penggunaan obat ARV pada sebagian orang mengalami beberapa efek samping, salah satunya penurunan hemoglobin $(\mathrm{Hb})$ yang di pengaruhi oleh faktor durasi terapi dan kadar CD4. Semakin tinggi takaran obat yang di pakai, semakin berat efek sampingnya, dapat ditinjau juga dengan lama penggunaan obat. Jika proses penguraian obat dalam darah lebih lambat dari yang sewajarnya, maka tingkat obat dalam darah akan lebih tinggi, dan hal ini lebih mungkin mengakibatkan efek samping (Spiritia, 2014). Penurunan hemoglobin terkait ART (Antiretroviral Terapi) pada penderita terinfeksi HIV/AIDS kemungkinan besar terjadi akibat tiga mekanisme yaitu penurunan produksi sel darah merah, peningkatan destruksi sel darah merah, dan inefektivitas produksi sel darah merah. Umumnya, ketiga mekanisme tersebut termasuk infiltrasi sumsum tulang yang disebabkan oleh neoplasma atau infeksi, penurunan erythropoietin endogen, anemia hemolitik, penggunaan obat-obatan mielosupresif seperti AZT (Zidovudin), atau akibat penggunaan berbagai macam obat (Widhi, 2015). AZT adalah salah satu unsur duviral pada ART, cenderung menekan sel darah merah atau menghambat pertumbuhan sel-sel hematopoetik pada sumsum tulang penderita AIDS, sehingga mengalami penurunan Hb yang rendah (Spiritia, 2014).

Penderita HIV/AIDS yang mendapatkan terapi ARV perlu pemeriksaan intensif pada hemoglobin penderita sebulan sekali dalam 3 bulan pertama karena dalam beberapa bulan pertama obat ARV akan mentoksisitas pada supresi sumsum tulang yang diinduksi obat seperti penurunan haemoglobin $(\mathrm{Hb})$. Selanjutnya pemeriksaan dilakukan minimal 6 bulan sekali setelah inisiasi ART guna untuk melihat kondisi penderita diharapkan mengurangi resiko terjadinya penurunan hemoglobin lebih parah (Kementerian Kesehatan RI, 2014).

\section{Metode}

Desain dalam penelitian ini adalah analitik korelasi dengan rancangan penelitian cross sectional. Populasi seluruh penderita HIV/AIDS yang menjalani terapi Antiretroviral dan terdaftar di Poli VCT RSUD Prof. Dr. Soekandar Kabupaten Mojokerto yang berjumlah 65 responden, sampel dalam penelitian ini diambil dengan teknik non probability sampling tipe purposive sampling dengan kriteria penderita HIV/AIDS yang menjalani terapi pengobatan ARV secara teratur di Poli VCT RSUD Prof. Dr. Soekandar Kabupaten Mojokerto sebanyak 25 responden. Alat ukur yang digunakan lembar observasi rekam medis pasien dan alat cek $\mathrm{Hb}$ (Quick Chek $\mathrm{Hb}$. Analisa data yang digunakan adalah Spearman rho.

\section{Hasil}

Tabel 1. Lama penggunaan obat ARV terhadap kadar hemoglobin pada penderita HIV/AIDS Tahun 2016

\begin{tabular}{|c|c|c|c|c|c|}
\hline \multicolumn{6}{|c|}{ Kadar Hemoglobin } \\
\hline & & $\begin{array}{l}\text { Ting } \\
\text { gi }\end{array}$ & $\begin{array}{l}\text { Nor } \\
\text { mal }\end{array}$ & $\begin{array}{l}\text { Rend } \\
\text { ah }\end{array}$ & Total \\
\hline \multirow{7}{*}{$\begin{array}{l}\text { Lama } \\
\text { Penggu } \\
\text { naan } \\
\text { Obat } \\
\text { ARV }\end{array}$} & \multirow{2}{*}{$\begin{array}{l}\text { Pen } \\
\text { dek }\end{array}$} & 1 & 7 & 3 & 11 \\
\hline & & 4,0 & 28,0 & 12,0 & $44,0 \%$ \\
\hline & \multirow{3}{*}{$\begin{array}{l}\text { Sed } \\
\text { ang }\end{array}$} & & & & \\
\hline & & 0 & 2 & 12 & 14 \\
\hline & & $0 \%$ & $\begin{array}{l}8,0 \\
\%\end{array}$ & $\begin{array}{l}48,0 \\
\%\end{array}$ & $56,0 \%$ \\
\hline & \multirow{2}{*}{$\begin{array}{l}\mathrm{La} \\
\mathrm{ma}\end{array}$} & 0 & 0 & 0 & 0 \\
\hline & & $0 \%$ & $0 \%$ & $0 \%$ & $0 \%$ \\
\hline \multirow[t]{2}{*}{ Total } & & 1 & 9 & 15 & 25 \\
\hline & & $\begin{array}{l}4,0 \\
\%\end{array}$ & $\begin{array}{l}36,0 \\
\%\end{array}$ & $\begin{array}{l}60,0 \\
\%\end{array}$ & $100,0 \%$ \\
\hline \multicolumn{6}{|c|}{$\begin{array}{l}\text { Sumber : Data Primer, } 2016 \\
\text { Berdasarkan tabel dapat diketahui } \\
\text { bahwa pasien yang menjalani pengobatan } \\
\text { ARV sedang ( } 12-36 \text { bulan) memiliki kadar } \\
\text { hemoglobin rendah (Hb reguler turun } 1 \text { gr/dl } \\
\text { selama menjalani terapi ARV) sebanyak } 12 \\
\text { responden }(48,0 \%) \text {. }\end{array}$} \\
\hline
\end{tabular}


Hasil uji Spearman rho diperoleh data $\rho$ $(0,002)<\alpha(0,05)$ artinya $\mathrm{H}_{0}$ ditolak artinya ada hubungan antara lama pengunaan obat ARV terhadap kadar hemoglobin pada penderita HIV/AIDS di Poli VCT RSUD Prof. Dr. Soekandar Kabupaten Mojokerto.

\section{Pembahasan}

Hasil penelitian menunjukkan bahwa pada pasien yang menjalani pengobatan ARV sedang (12-36 bulan) memiliki kadar haemoglobin rendah sebanyak 12 responden $(48,0 \%)$.

Hal ini sesuai dengan teori dari (Handayani, 2008) bahwa faktor yang dapat menyebabkan terjadinya kadar hemoglobin dari konsumsi obat-obatan tertentu, diketahui bahwa beberapa jenis obat-obatan tertentu yang mungkin sering dikonsumsi dapat menyebabkan kemampuan metabolisme tubuh untuk menyerap vitamin atau zat besi bahkan berakibat pada infeksi lambung. Seperti obat aspirin, obat anti-inflamasi, antacid, pil KB, obat anti arthritis dan obat antiretroviral jenis NRTI gologan Zidovudine.

Beberapa orang yang memakai obat antiretroviral (ARV) mengalami beberapa efek samping.Semakin tinggi takaran obat yang dipakai, semakin berat efek sampingnya, dapat ditinjau juga dengan lama dalam penggunaan obat.Jika tubuh kita lebih kecil dari rata-rata, kita mungkin mengalami lebih banyak efek samping. Jika proses penguraian obat dalam darah lebih lambat dari yang sewajarnya, maka tingkat obat dalam darah akan lebih tinggi, dan hal ini lebih mungkin mengakibatkan efek samping. Salah satu unsur di dalam duviral, semakin lama pengobatan dengan dosis tinggi, semakin cenderung menekan sel darah merah dan mengalami gejala kadar hemoglobin dengan hemoglobin yang rendah (Spiritia, 2014).

Kadar hemoglobin terjadi pada umumnya dikarenakan beberapa faktor resiko yang dapat menyebabkan produksi sel darah merah berkurang salah satunya dari mengkonsumsi obat-obatan tertentu.Diketahui bahwa beberapa jenis obat-obatan tertentu yang mungkin sering dikonsumsi dapat menyebabkan kemampuan metabolisme tubuh untuk menyerap vitamin atau zat besi bahkan berakibat pada infeksi lambung, salah satunya merupakan terapi pengobatan antiretroviral jenis NRTI golongan Zidovudine jenis duviral (Handayani, 2008).

Penurunan kadar hemoglobin merupakan efek samping paling berat akibat penggunaan terapi pengobatan antiretroviral (ARV) jenis duviral. Salah satu unsur di dalam obat antiretroviral jenis duviral yaitu, semakin lama penggunaan obat ARV dengan dosis tinggi maka semakin cenderung menekan sel darah merah dan mempengaruhi kadar hemoglobin sehingga mengakibatkan terjadinya kadar hemoglobin yang terus menurun pada penderita HIV/AIDS.Penurunana kadar hemoglobin dapat terjadi dikarenakan efek samping dari pengobatan Antiretroviral yang cenderunguntuk menekan jumlah virus dengan menghambat proses replikasi virus HIV dalam sel CD4. Penekanana sel darah merah identik dengan penurunan hemoglobin karena pada obat antiretroviral jenis zidovudine yang cenderungmenghambatan enzim reverse transcriptase dan mengakibatkan kerusakan sumsum tulang belakang sehingga menyebabkan terjadinya kadar hemoglobin dalam darah sangat rendah.

\section{Simpulan}

Terdapat hubungan lama penggunaan obat ARV terhadap kadar hemoglobin pada panderita HIV/AIDS di Poli VCT RSUD Prof. Dr. Soekandar Kabupaten Mojokerto. Semakin lama penggunaan obat ARV dengan dosis tinggi maka semakin mempengaruhi kadar hemoglobin sehingga mengakibatkan terjadinya penurunan kadar hemoglobin pada penderita HIV/AIDS.Penurunan kadar hemoglobin dapat terjadi dikarenakan efek samping dari obat Antiretroviral jenis zidovudine yang cenderung menghambatan enzim reverse transcriptase dan mengakibatkan kerusakan sumsum tulang belakang sehingga menyebabkan kadar hemoglobin darah turun hingga dapat mengalami anemia sedang maupun berat.

\section{Saran}

Bagi Responden

Responden diharapkan dapat mengetahui dan mengaplikasikan pedoman penggunaan terapi pengobatan obat antiretroviral dengan tepat, sehingga dapat memahami efek samping obat antiretroviral 
dengan cara mengkonsumsi makanan yang tinggi zat besi dan vitamin sehingga dapat menekan terjadinya anemia.

Bagi Instalasi Pelayanan Kesehatan Instansi Pelayanan Kesehatan dapat memberikan motivasi dan pengarahan kepada penderita HIV/AIDS dengan memberikan konseling serta mongontrol dalam pelaksanaan terapi pengobatan ARV, sehingga penderita HIV/AIDS mampu memahami kondisi kesehatannya terkait dengan efek samping penurunan hemoglobin dan kontrol dari efektifitas regulasi dosis penggunaan ARV.

Bagi Peneliti Selanjutnya

Peneliti selanjutnya diharapkan dapat meneliti pengguna ARV lama (>36 bulan) sehingga dapat mengetahui dengan jelas bahwa semakin lama penggunaan ARV maka akan semakin memepengaruhi kadar hemoglobin dan efek samping obat yang lain dalam menjalani terapi pengobatan antiretroviral, yang diharapkan pada nantinya hasil penelitian dapat diaplikasikan pada pelayanan kesehatan.

\section{Daftar Pustaka}

Dinas Kesehatan Kabupaten/Kota Mojokerto. (2014). Profil Kesehatan Kabupaten/ Kota Mojokerto Tahun 2013.

Dinas Kesehatan Provinsi Jawa Timur. (2013). Profil Kesehatan Provinsi Jawa Timur tahun 2012.

Ditjen PP \& PL Kemenkes RI. (2014, September). Statistik Kasus HIV/AIDS di Indonesia.

Green, C. (2007). HIV \& TB. Yogyakarta: Yayasan Spiritia.

Green, C. (2009). Pengobatan untuk AIDS: ingin mulai ? Yogyakarta: Yayasan Spiritia.

Handayani, W. (2008). Buku Ajar Asuhan Keperawatan pada Klien dengan Gangguan Sistem Hematologi. Jakarta: Salemba Medika.

Kementerian Kesehatan RI. (2015). Data dan informasi tahun 2014 (profil kesehatan indonesia).

Kementerian Kesehatan RI. (2014). InfoDATIN (Pusat Data dan Informasi),situasi dan analisis HIV/AIDS.
Kementerian Kesehatan RI. (2011). Pedoman Nasional tatalaksana klinis infeksi HIV dan Terapi Antiretroviral pada Orang Dewasa.

Spiritia, Y. (2014). Lembar Informasi 550 Tentang Efek Samping Obat ARV. 550 .

Piritia, Y. (2014). Lembar Informasi 552 Tentang Efek Samping Obat ARV. 552.

Veronica. (2013). Faktor-faktor yang berhubungan dengan kepatuhan ODHA dalam menjalani terapi ARV.

WHO. (2014, Juli). Global Update on the Health Sector Response to HIV. World Health Organization .

Widhi, G. (2015). Faktor-faktor yang memepengaruhi kejadian anemia pada pemakaian zidovudin pasien HIV/AIDS. 4. 